\title{
Opposing the Power of Lies, Bullshit and Fake News: the Value of Truth
}

\section{Alison MacKenzie ${ }^{1} \cdot$ Ibrar Bhatt $^{1}$}

Published online: 13 November 2019

(C) The Author(s) 2019

\begin{abstract}
'Post-truth' politics poses a serious challenge to the values of truth, and consequently trust. Sections of mainstream political parties and the media do not appear to have basic knowledge or insight into processes that underpin our institutions, and we are confronted with the proliferation of lies, fake news and bullshit - and profound ignorance. We will explore the distinctions between truth and truthfulness, and lies and deceit to centrally argue that truth has considerable intrinsic and instrumental value that should be protected and respected. Truth is invaluable to the integrity of the person, institution and nation, and a climate of trust to the proper functioning of democracy. While it may be expedient to distort or ignore the truth, we value truth in ways that cannot be reduced to its practical value. This is because it is very closely related to trust, sincerity and integrity. Indifference to truth, and the cynical espousing of lies, fake news or bullshit can be destabilising and harmful, as Brexit (the United Kingdom's process of withdrawal from the European Union) is painfully revealing. Deception constitutes a limit to our will: how can we make informed choices if the information we receive is inaccurate, false or untrue? As our information ecosystem becomes increasingly complex, unpredictable and balkanised, educators have a vital role in helping an informed public navigate what it encounters online.
\end{abstract}

Keywords Truth $\cdot$ Lies $\cdot$ Bullshit $\cdot$ Fake news $\cdot$ Brexit

Alison MacKenzie

A.Mackenzie@qub.ac.uk

Ibrar Bhatt

I.Bhatt@qub.ac.uk

1 SSESW, Queen's University, Belfast, UK 


\section{Introduction}

George Orwell, in his essay on 'Looking back on the Spanish War' (1968), wrote that:

Early in life I noticed that no event is ever correctly reported in a newspaper, but in Spain, for the first time, I saw newspaper reports which did not bear any relation to the facts, not even the relationship which is implied in an ordinary lie. (256)

He continues that the papers reported battles that never happened, silence over the killing of hundreds of soldiers, and troops denounced as traitors and cowards. The scale of the lies, omissions and silences frightened him,

because it often gives me the feeling that the very concept of objective truth is fading out of the world. After all, the chances are that those lies, or at any rate similar lies, will pass into history... Yet, after all, some kind of history will be written, and after those who actually remember the war are dead, it will be universally accepted. So for all practical purposes the lie will have become the truth. (258)

He also understood the danger of falsifying history and denying that history could be objectively written:

I know it is the fashion to say that most of recorded history is lies anyway ... but what is peculiar to our own age is the abandonment of the idea that history could be truthfully written .... The implied objective of this line of thought is a nightmare world in which the Leader or some ruling clique, controls not only the future, but the past. (258)

The reporting of lies frightened him more than bombs, and after the experience of WWII that was a statement of some significance. Orwell was writing about the pervasive use of propaganda by totalitarian regimes in Spain, Germany and the Soviet Union. He was deeply concerned about what would happen if the idea of objective truth were undermined, and alternative realities were presented as true and truthful, fearing that lies would pass into history as truth. If Orwell's essay seems irrelevant to our present day, perhaps too far-fetched to be overly concerned about in a liberal democracy, he reminds the reader that in 1925 the totalitarian nightmare to come would have seemed unthinkable. The English, he wrote, underrated the power of totalitarianism to take hold and violate truth because 'our traditions and past security have given us a sentimental belief that it all comes right in the end ... '. (259)

Currently, in the United Kingdom (UK), the country we take as our focus of analysis, Brexit 'post-truth' politics poses a serious challenge to the values of truth and trust (as do numerous cognate populist movements across the world). The Brexit process, the means by which the UK will negotiate its withdrawal from membership of 
the European Union (EU) following the referendum in $2016^{1}$, has revealed that large sections of mainstream political parties and the mainstream media lack 'even a basic degree of knowledge or insight about institutions, relationships', processes and forces (such as those on which the $\mathrm{EU}^{2}$ and universities operate) which are 'crucial to national life', according to Dougan and O'Brien (2019: 200). We are confronted with 'profound ignorance' (197), contributing to public misunderstanding, and the ready proliferation of deceit and lies. The Leave Campaign employed four tactics which Dougan and O'Brien have categorised as follows: to tell lies; sell fantasies; to suppress and abuse the opposition; and blame scapegoats (201-202). These tactics have been successful to such an extent that, for many commentators, politicians and academics, Brexit is:

... one of the greatest victories notched up so far by the forces of illiberal authoritarianism which are currently on the march across the developed world and which together pose the gravest threat to the institutions and values of liberal social market democracy since 1945. (Dougan and O’Brien 2019: 203)

\section{Orwell's cautionary analysis seems correct.}

The central claim in this article is that truth has considerable intrinsic and instrumental value that should be protected and respected. Truth is important to the integrity of the person, institution and nation, to the proper functioning of democracy, and, of course, to how to live well. Indifference to the truth erodes trust, and trust is indispensable to truthfulness (Williams 2002). The rapid proliferation of falsehoods throughout digital environments is such that controlling the volume of disinformation seems almost impossible, although, of course, social media is also an important source of informed and truthful analyses. Further, our often unwitting reliance on algorithms to curate our newsfeeds can also be problematic because we are increasingly using social media as our source of news, views and evidence, leaving us susceptible to false information and to manipulative, adversarial actors.

We therefore need to trust that the information we encounter online through social media and online searches is reliable and accurate; if it is not, we cannot make informed judgements or be certain that what we are claiming is true or false. There is, as we recently claimed (MacKenzie and Bhatt 2019), concern that fake news in online platforms is undermining the legitimacy of the press, the democratic process, and the authority of science, the social sciences and qualified experts to interpret events and to make reasonable claims about how we should act. The British government also appears to be unabashedly engaged in attempts to rewrite history, and to present as true that which is patently not true such as that we voted to leave the EU without a deal in the 2016 UK referendum. $^{3}$

\footnotetext{
$152 \%$ voted to leave the European Union.

2 The wealth of lies, myths and distortions on what the EU actually does can be found here: https://blogs.ec. europa.eu/ECintheUK/euromyths-a-z-index/.

3 Though many Brexiteers claim that the voters knew exactly what they were voting for in 2016 . That they could not have known (since there were only two options on the ballot paper: remain or leave) is here explained by Otto English: https:/www.independent.co.uk/voices/brexit-theresa-may-leave-voters-remain-eureferendum-campaign-deal-a8740526.html.
} 
If we are to rely on what we are told, the speaker must not only be sincere in what is asserted, but also honest—not devious, wilfully inaccurate or misleading. While it may be at times expedient to distort the truth or to ignore it, we nevertheless value truth in ways that cannot be reduced to its mere practical value because it is very closely related to trust, sincerity and integrity. Lies and bullshit also have instrumental value but for very different reasons to the value we grant to truth: liars usually seek to evade, suppress or mislead for some personal or party political advantage, and at the expense of the hearer. Indifference to truth and truthfulness can be harmful and destabilising as Brexit in the UK and the Trump administration surely testify. The trouble with lies, bullshit and fake news is that they pollute personal and public life, and place a limit on what we can effectively and reasonably do, given the standard of information we have. This is because lies constitute a limit to our will: without an accurate account of our reality, we are disabled from intelligently formulating and advancing our goals, making sensible judgements, or speaking with honesty and clarity; only if we have accurate and relevant information can we can act with confidence and with a reasonable degree of success.

Without the truths we require, Frankfurt (2006: 44) informs us, 'we have nothing to guide us but our own feckless speculations or fantasises and the importunate and unreliable advice of others'. This 'mindless groping' may help us for a while, Frankfurt suggests, but without sufficient information to avoid obstacles and dangers, we are condemned to know nothing of them until it is too late, by which time we may have learned 'that we have already been defeated' (44). Brexit, and the propaganda, myths, semi-truths, claims and counter claims that it has abundantly spawned, provides numerous examples of 'mindless groping' and 'feckless fantasises' (with potentially destabilising consequences to the union of the UK and the quality of life of nearly all), revealing the depth to which politicians' cavalier relationship with the truth will go if it suits their party political or self-interested purposes.

\section{The Value of Truth}

'Truth?', asked Pilate of Jesus, 'What is that?' Although fiendishly difficult to define, truth is a highly complex concept (how do we know that something is true?) that is frequently challenged and regarded with scepticism - and disregard. Frankfurt (2006) in his prolegomenon, On Truth, cites the observation of his editor that "while no one has any trouble recognizing that there is plenty of bullshit around, quite a few people remain stubbornly unwilling to acknowledge that there might be - even in principle such a thing as truth' (8-9). Because defining truth is so forbidding, Williams (2002) advises that we should resist demands for a definition because it 'belongs to a ramifying set of connected notions, such as meanings, reference, belief ...' (63). However, while truth is an 'indefinable' concept it is not 'mysterious, ambiguous or untrustworthy' (Davidson, cited in Williams 2006: 63). We know what it means to seek and state the truth, to be truthful in what we convey to others, and the essential value of others being truthful with us. In being truthful we are more likely to command trust and confidence that the testimony we are providing is factual, and a sincere representation of our beliefs. There is a dialectical relationship between truth and trust: we are more likely to trust a person who doesn't lie, although this does not necessarily mean that we will 
accept everything that they tell us. Rather than formally engaging in a precise account of what truth means, we will take it to mean that it entails qualities such as 'sincerity", 'accuracy', 'trust', 'trustworthiness' and 'truthfulness'. We also need facts to obtain a corresponding truth.

However, even to speak of 'truth' is deeply contentious, entangling interlocutors in discouraging discussions about what constitutes truth and from whose perspective something is true. Discouraging discussions also ensue on whether we can agree that there is such a thing as an objective reality (or standard of work), even though sceptics of the existence of objective truths might concede that they believe their statement to be true that there is no such thing since the objective truth of the realities under discussion are relative. The best way out of the subjective morass that one truth is as good as another is to accept that there are degrees of truth, and that people offer truthful accounts of what they believe the case to be. This is a familiar epistemic relativist position. ${ }^{5}$ What makes sense to one person, may not make sense to another. However, this position does not obviate the requirement that interpretations should be responsive to truthfulness, and that they should provide us with the truth about an event in the sense that it should not be false, lie or mislead. Processes of verification ${ }^{6}$ (or falsification) also rely upon a notion of truth.

How do we come to know or trust that something is true? There are ways of coming to believe in something that are not desirable: indoctrination, misrepresentation, manipulation, distortion, illegitimate persuasion, oratory, flattery, desire, sentimentality, nostalgia and lies. We need the right reasons to believe that something is true. We can achieve that by having a stubborn respect for facts, for accuracy, and for honest, objective, reporting on the best available evidence, all things (honestly) considered, and in the disinterested pursuit of the truth for its own sake. Establishing that something is true means rejecting partiality and arbitrariness - and wishful thinking that something be true. This might be regarded as the 'externalist' (existing independently of the individual) take on objectivity (see Rose 2019 this issue).

Nevertheless, if the non-relativist feels some caution in talking about 'truth', it is that one might be accused of being essentialist, universalising, and disrespectful of alternative realities or 'truths'. How one understands truth is, according to the sceptic, a matter of where one stands with respect to that truth. Simple, everyday truths such as that my name is Alison is an easy fact to verify: it is unqualifiedly true and I can produce a birth certificate to prove it. While we might all identify certain propositions to be true (Boris Johnson, at the time of writing this article, is the Prime Minister of the United Kingdom) and others false (Boris Johnson is the reigning British monarch), it becomes more complex when we try to establish the truth among competing claims such as whether or not the United Kingdom should leave the EU, and under what terms. In this

\footnotetext{
${ }^{4}$ Although even claims to sincerity may mislead. Former Prime Minister, Tony Blair, insisted that he invaded Iraq in the sincere belief that Saddam Hussein had weapons of mass destruction. In his resignation speech to his Sedgefield constituents (England), he stated: 'Hand on heart, I did what I thought was right. I may have been wrong, that's your call. But believe one thing, if nothing else. I did what I thought was right for our country' (2007).

${ }^{5}$ For a brief overview on how on the development of epistemic relativism, see Kenan Malik (2017) here: https://kenanmalik.com/2017/02/05/not-post-truth-as-too-many-truths/.

${ }^{6}$ Verification in the social sciences 'is the process of checking, confirming, making sure, and being certain' (Morse et al. 2002: 17). See also the seminal work of Guba and Lincoln (1981) who speak of trustworthiness in research as consisting in four elements: credibility, transferability, dependability and confirmability.
} 
exemplary case, it seems impossible to establish who is right, what 'the truth' is, who has the right or authority to claim the truth, or whom to trust, such is the fervid and rabid way in which the debates proceeded on this issue at the time leading up to, and after, the referendum campaign of 2016. The proliferation of lies, bullshit and fake news online goes on unabated because of the investment in the untruths of Brexit. What is true is that very many lack confidence and trust in the integrity of the current UK government, particularly the current Prime Minister ${ }^{7}$, because he is judged (with evidence) to be a liar. ${ }^{8}$

The glibness of assertions that truth is relative becomes apparent when one considers what is at stake in building a high rise or a bridge, in diagnosing an illness and prescribing treatment, obtaining the optimum conditions to yield healthy crops - or leaving the EU without a deal. Each demands deep and extensive knowledge, ongoing scholarly research, respect for science, care in reporting the research, interpreting treaties and protocols, all researched by experts who devote themselves to understanding such issues so that no harm can come to individuals or to society. It also requires trust in experts which British citizens have been worryingly discouraged from doing by Conservative Party MP, Michael Gove ${ }^{9}$ before the EU referendum in 2016. The evidence against experts can be seen on, for example, Twitter feeds, where facts are often disparagingly dismissed and accusations of ideological bias or 'surrendering, 10 our democracy to the EU are common. We are being asked to distrust the authority of experts to speak on issues about which they know a great deal.

Facts are what they are regardless of what we believe about them, even when there is a backlash against, or denial about, those facts (the safety of vaccines or the evidence for climate change). True, the engineer, doctor, farmer or trade deal analyst may not be interested in a general or abstract notion of truth as such. The researcher may be interested only in discrete facts from which truths relevant to their specialism can be inferred, and so may refrain from infusing the facts with value. However, each specialist would surely have something to say about the harm of not vaccinating children against measles or continuing to emit carbon dioxide into the atmosphere. There are clear facts and those facts have something to tell us about what we ought to

\footnotetext{
${ }^{7}$ A YouGov poll, 3 September 2019, asked: How much, if at all, do you trust Boris Johnson to make the right decisions on the issue of Brexit? Only $13 \%$ trust Johnson a lot, 38\% do not trust him at all, while $17 \%$ trust him only a little. See https://whatukthinks.org/eu/questions/how-much-if-at-all-do-you-trust-boris-johnson-tomake-the-right-decisions-on-the-issue-of-brexit/.

${ }^{8}$ See David Hare (2019, September 4) in the New Statesman https://www.newstatesman.com/politics/uk/2019 /09/we-know-boris-johnson-liar-it-s-his-enablers-who-are-most-culpable.

${ }^{9}$ This was stated in an interview with Faisal Islam on Sky News in 2016 (June 3). Interestingly, Gove suggests that we should seek out the dissenting voice to obtain trustworthy information. 'If you think it's just bogus nonsense then fine, but always test every proposition. The idea that things should be taken simply on trust because of someone's position I think is an invitation to intellectual conformity and what we need is a vigorous, debating, dissenting culture'. The problem with this kind of argument is that we are being asked to trust the best constructed argument. Persuasion not facts.

See https://www.chathamhouse.org/expert/comment/michael-gove-trouble-experts. In his recently published memoir, former Prime Minister, David Cameron, describes Johnson and Gove 'ambassadors for the experttrashing, truth twisting age of populism'. See, for example, https:/www.bbc.co.uk/news/uk-politics49705213.

${ }^{10}$ The European Union (Withdrawal) (No. 2) Act 2019, also known as the Benn Act, after Hillary Benower, MP, to prevent the UK from leaving the EU without a deal and to request an extension to the Brexit withdrawal date of 31 October 2019. Boris Johnson decried the bill as the 'surrender bill'.
} 
do. Undermining the authority of truth, or the expert, leaves citizens vulnerable to persuasive oratory, rhetoric, illegitimate persuasion, manipulation and so on, creating a void into which lies, bullshit and fake news flows and flourishes. Indifference to, denial of, or ignorance about the truth and their corresponding facts can be fatal.

According to Frankfurt, we continue to contend with the 'impermeable obduracy' of relativism because the distinctions 'between what is true and what is false are ultimately guided by nothing more indisputably objective, or more compellingly authoritative, than our individual points of view' (16). Sceptics (deniers of any kind) also insist that it is difficult to know or assert a truth because the person may be constrained by social pressures to know what is, in fact, true. Anyone who lives in Northern Ireland, or who knows the history of this part of the UK, will understand how difficult it is to assert objective truths about the conflict known as The Troubles - and may assent to the belief that there is no such thing as objective reality, only truthful and sincerely believed representations at best. The present crisis in the UK over Brexit may also make it fiendishly difficult to judge whether leaving will afford us new opportunities for market penetration or whether leaving will result in economic catastrophe. The availability of the internet, of (Dr) Google in particular, means that answers, opinions and articles can be quickly found (and see Bhatt and MacKenzie 2019 for a full discussion). Answers obtained quickly are not the same as researching complex questions, and users may be placing too much trust in Google's results, mainly because they do not know how Google works. Unlike the novice, experts know how to use high quality sources, up-todate theoretical frameworks, and critical thinking based on their experience in a particular field. An expert may also use different search engines and browsers to search for the same thing in order to minimise algorithmic biases because she is cognisant of the failings of the procedural tool.

Doubts about establishing objective truths may be more persistent in the Humanities or the Arts. It is a matter of subjective opinion (the internalist take on the argument) on whether, say, a painting is a great work of art or whether the historian has accurately and without bias portrayed the rise of the Third Reich. Rather than truth, we are confronted with a 'battle of rhetorics' (Williams 2002: 2). Who has the authority to say how things really were?

However, these disciplines, too, have their standards and means by which to check for accuracy, authenticity, originality, technique and style, and the proper use of primary and secondary sources. The extent to which we can speak of a truthful account will depend on the formation of that account, whether the formation has been governed by considerations of truth and truthfulness. Even if we reject evaluative statements on whether a painting is a great painting or a book is a great work of historical theory (What is History? by EH Carr, for example), there are limits to what we can claim to be true or false, regardless of our subjective stances or selective strategies: at some point in the chain of reasoning we will find that we are reliant on non-normative judgements: $\mathrm{X}$ is the case. Even those who claim that historical accounts are ideological constructs have to rely on a narrative that claims some historical truth if the account is not to sink into absurdity. When asked, for example, what future historians would say about the First World War, the French diplomat Georges Clemenceau replied 'they will not say that Belgium invaded Germany' (cited in Frankfurt 2006: 21). John Constable's Hay Wain is a great painting, and it is incontrovertibly true that Hitler was the Chancellor of Germany and later Führer (in 1934). Nevertheless, it may be contended, these are 
secure truths, manifest and incontrovertible, easy to discuss and reach agreement. It may be more difficult to assess whether Hitler alone was responsible for the Second World War or whether he had a fully worked out plan to take power or lift Germany from recession. The facts that the historian AJP Taylor (1961) was able to establish through brilliant scholarly research is that: he didn't. Hitler had conviction and determination. What is not in doubt is that he contributed to the rise of anti-Semitism and the creation of road-works. That this is all true can be checked against the historical records. Taylor's evidence and argument moved the historiography of the period on. ${ }^{11}$

The point, as Williams (2002) so eloquently puts it, is that doubt about truth while demanding truthfulness is an unstable situation. He asks:

if you do not really believe in the existence of truth, what is the passion for truthfulness a passion for? Or ... in pursuing truthfulness, what are you supposedly being true to? This is not an abstract difficulty or just a paradox. It has consequences for real politics, and it signals a danger that our intellectual lives, particularly in the humanities, may tear themselves to pieces. (2)

To deny obvious facts is to succumb to irrationality; but to fetishise facts is also unwise. On the standard account of rationality ${ }^{12}$, to be rational is to be responsive to reasons, and reasons are constitutive of facts. The fact that Boris Johnson is the Prime Minister constitutes a reason to believe that he is the Prime Minister. It is also a fact, and conclusively true, that he visited Luxembourg on September 16, 2019, to progress talks on the UK's exit from the EU with Xavier Bettel, the Prime Minister of Luxembourg. The more complex question is: did he attend the meeting with the sincere aim of furthering the negotiations to leave the EU with a deal? Or was this a cynical exercise to blame the EU in the event of a No-Deal and to keep the support of ardent Brexiteers? On whom and on what can we trust to make a reasonable judgement on what the facts are and what the truth is? On questions of trust we have to rely on what we know about the character of the person: past actions and assertions, moral probity and consistency, and commitment to principlesand the accounts of those who know the Prime Minister well. On current accounts, from a range of well-regarded and less regarded politicians in the UK and in the EU, we have evidence to doubt the honesty and integrity of the UK's Prime Minister ${ }^{13}$. As Bettel stated, gesticulating to an empty podium where Boris Johnson should have stood for the press conference on that day:

\footnotetext{
${ }_{11}$ Taylor's position was highly controversial and is still debated. Some regard it as being of dubious value. See, for example, Goda (2002). Historians argue over what happened in the past on the basis of evidence. There is a knowable and true past but it is a matter of dispute and the weight of evidence is key. (Thanks to Professor Ian Thatcher for making this point. Personal correspondence.)

${ }^{12}$ Cf Aristotle and Immanuel Kant, and philosophers from the Enlightenment tradition.

${ }^{13}$ For example, David Cameron. See https://www.theguardian.com/politics/2019/sep/15/david-cameronslammed-for-horrendous-mistake-brexit-referendum; former members of government such as Kenneth Clarke and Lord Michael Heseltine; his former employer at the Daily Telegraph, Max Hastings (2019). See for example, https:/www.theguardian.com/commentisfree/2019/jun/24/boris-johnson-prime-minister-toryparty-britain. Guy Verhofstadt, the chief Brexit representative for the European Parliament.
} 
People need to know what is going to happen to them [British people living in Luxembourg] in six weeks [sic] time. They need certainty and they need stability. You cannot hold their future hostage for party political gain ....

When asked by reporters on whether Downing Street was pursuing a sham negotiation in order to pin the blame on the EU for a no-deal Brexit, Bettel (cited in Boffey 2019) responded:

I told him, 'I hear a lot but I don't read a lot'. If they want to discuss anything we need to have it written [down] .... Don't put the blame on us because they [the UK government] don't know how to get out of the situation they put themselves in.

The simple truth about the truth is that 'reality, and accordingly the truths about its properties, are what they are, independent of any direct or immediate control by our will. We cannot alter the facts nor, similarly, can we affect the truth about the facts, merely by an exercise of judgement or by an impulse of desire' (Frankfurt 2006: 54-55). This may be read as a positive and confident account of the value of facts and truths. With respect to history (and what current affair does not become history?), matters may be less straightforward: the historian is necessarily selective in what facts of history are chosen, and history is read through the mind of the historian. As EH Carr (1961: 12) stated: 'The belief in a hard core of historical facts existing objectively and independently of the interpretation of the historian is a preposterous fallacy'. However, while the reconstitution of the past is dependent on the historian's interpretation, it nevertheless rests on empirical evidence, and not any old interpretation will do. Facts have to be respected, all known and relevant facts should be included, and these have to be interpreted in such a fashion that the result is not propaganda or fiction. What objectivity may mean here is progressive interpretation of events which provides deeper and expanding insights into a course of events that supersedes and includes past interpretations (Carr 1961). Conflicts can be rationally settled: increasing knowledge produces agreed certainty and consensus on (once) disputed issues. Difference of interpretation need not mean difference on the validity or rigour of the argument being asserted.

What marks something as a truth as opposed to being true is that a truth embodies facts and value judgements. While it is factually true, as we said earlier, that my name is Alison, it seems odd to call this a truth: it is devoid of any value content. To claim that the Prime Minister is a liar, as is often alleged, may not only be true (it can be verified), it is also a truth about him (a quality of his character that can be assessed. The facts correspond to reality and to truth). Supporters may disagree that the Prime Minister is a liar, but they will have put forward evidence that those who claim he is a liar are misjudged or have misunderstood him. The importance of all this to the value of truth is that Johnson and politicians of a similar ilk (Farrage and Trump, for example), in their cavalier undermining of the authority of truth (sincerity, truthfulness, authenticity, accuracy and so on), diminish their own authority to speak on it, 
and thereby erode trust and confidence. The perils of lying, or of manipulating the truth is that

whatever benefits and rewards it may be sometimes possible to attain by bullshitting, by dissembling, or through sheer mendacity, societies cannot afford to tolerate anyone or anything that fosters a slovenly indifference to the distinction between true and false' (Frankfurt 2006: 33).

Healthy societies need access to reliable factual information and to have mechanisms which deflect or hold up to scrutiny 'troublesome infections of mistaken beliefs' (34).

\section{The Harm of Deception and Lying}

We often find reasons to lie. Fear, shame, greed, selfishness and lust can drive us to lie. We lie to save face, to protect others from harm, to maintain privacy, for the public good, for noble causes, and to the sick and dying. We also lie to hedge against 'the discomfort of being truly seen'. The previous section was concerned with exploring truth and what we mean when we speak of truths, or when we say something is true or truthful. In part, this was an epistemological exploration of how we can know what we know, and claim to know it to be true or false. It was also an ethical exploration of the moral domain of truth telling, as the two domains often overlap and are, to an extent, indispensable to each other (Bok 1989: 9). They are not, however, identical: one domain is concerned with what can be known, with what is true or false, or truthful, the other with intended truthfulness (6). However, though they are not identical, it is often difficult to separate the ethical from the epistemological. As the preceding discussion has sought to show, if we claim that we cannot really know what is true or false, or whether knowledge is reliable, then accuracy or truthfulness need not matter so much, and there may be grounds to intentionally deceive: whose version of the truth or account of the facts do we want to hear? Orwell was alarmed that the reporting of events in the Spanish Civil War was not only factually wrong, it was intentionally wrong. Events were being fabricated to serve the national cause. 'The only propaganda line open to the Nazis and Fascists', Orwell (2000: 257), 'was to represent themselves as Christian patriots saving Spain from a Russian dictatorship'. This involved pretending that life under the Spanish government 'was one long massacre' (257). What deeply concerned Orwell was that the lie would become truth. Epistemologically and ethically, the rewriting of history to suit a particular view of the world results in the silence of those who ought to be known to us (the names of slaves on whose work the Empire parasitically depended), and ignorance about what actually happened. The harm of fake news of any kind is that it intends to deceive, to mislead and to distort in order to obtain a goal, and to falsify the facts to realise the goal, and thereby coerce people into believing what they should not, and disbelieving what they should. Some professions are regarded as being adept at engaging in such practices-journalism and politics, for example - but it should be clear why veracity and truthfulness should not be forgone. The deceiver may justify the deceit; the deceived rarely will, disputing the justification and protesting the harm to integrity and trust. 
If defining truth is difficult, it has, de Montaigne (35) suggested, at least but 'one face', in contrast to the lie which 'has a hundred thousand faces and an infinite field'. Lying, he stated 'was an accursed vice' because it is 'only our words which bind us together and make us human' (35). What is the difference between deception and lying? While we can be misled by any number of things and people, self-delusion, bias, poor sight, optical illusions, fatigue or poor communication, and so on, what marks out one kind of deception from another is whether there is an intention to deceive or mislead. According to Bok (1989) when we deceive others intentionally, 'we communicate messages meant to mislead them, meant to make them believe what we ourselves do not believe' (12). We deceive through gesture and disguise, 'by means of action or inaction', and through silence. When we lie, we intentionally deceive by stating something we know to be untrue and which is intended to deceive. The statement may be uttered, written, conveyed in 'smoke signals, Morse code, sign language' and so on. Lying forms part of the larger category of deception. To complicate matters, the extent to which a statement (or utterance, speech, act) is deceptive will be affected by self-deception, error and 'in variations in the actual intention to deceive'. These three factors, Bok writes, can be viewed as 'filters of irregular thickness, distortion, and color that alter the ways in which a message is experienced by both deceived and deceivers' (15). The deceiver can use these filters to play on the prejudices and fears of the target, to manipulate others' assessment of an event, and/or take advantage of confusion, error or competing claims. The heated debates over Brexit, we have suggested, provide an exemplary example of how deception can be nourished and thrive through denial, distortion and deflection, and many other such strategies.

The harm of deceit is that it can 'coerce people into acting against their will' (Bok 1989: 18), and we are all vulnerable to it. What we thought we were doing in good faith turns out to have been been guided by deception. To take a simple example: the typical approach to online searches begins with a query or question but not all search queries will yield equal results. There are many search terms for which, at a given time, the available relevant information is 'limited, non-existent, or deeply flawed' (Golebiewski and Boyd 2018: 3). These 'data voids' can be exploited by adversarial actors who use racialised, gendered or other discriminatory and weaponised phrases that are strategically placed on websites to entice users into reading their content, potentially exposing them to misleading or highly problematic information ${ }^{14}$ (Golebiewski and Boyd 2018).

Our choices, including the phrases we use to search for information online, are often dependent on the information available to us and what has entered our lexicon. If the information is incorrect, prejudicial or distorted by lies, the person will make a poor choice, or at least not the choice she thought she was making. If we accept that information, or knowledge, gives us power, that power will be affected by deception, altering the distribution of power so that the power of the liar is augmented, while the power of the deceived is diminished. Lies can also obscure or eliminate the alternatives available to us

\footnotetext{
${ }^{14}$ Creating websites using the term 'black on white crime' would not be used by anyone but white supremacist communities, according to Golebiewski and Boyd (2018: 4). Data voids also reflect bias and prejudice. Entering, for example, 'CEO' into a search engine will typically return pictures of men.
} 
(Bok 1989: 19), or make a situation certain or less certain than it actually is. To return to our example, Brexit provides ample evidence of the obscuration of truth and facts. The Supreme Court, the highest court in the UK, concluded that the Prime Minister, Boris Johnson, lied to the Queen when he asked for a prorogation (suspension) of parliament. The general view is that he sought prorogation in order to deter parliamentarians from scrutinising and debating the UK's withdrawal from the EU in order to realise a pure form of Brexitexit from the EU without a deal. The 11 justices of the Supreme Court unanimously ruled that prorogation for five weeks at the height of the Brexit crisis was 'unlawful, and of no effect' (The Supreme Court 2019: 2). The consequences are far reaching: the government seems to be in open warfare with parliament and the judiciary in order to achieve, at any cost, Brexit by 31 st of October 2019. It is hard not to agree with Grey (2019b) that we live in uncertain and dangerous times, and that the way that the UK is governed may well change as a consequence of a narrow, but highly influential and now dominant strand of Brexiteer ${ }^{15}$ thinking that has shown its 'willingness and even an enthusiasm to destroy anything and everything in the fanatical pursuit of the 'revolutionary' goal of Brexit in its supposedly purest form'. Grey describes this pursuit as a form of Jacobinism and identifies another strain which is McCarthyite in its zeal, 'a paranoid and ruthless quest to identify and denounce all who might be suspected of opposing that goal'.

That we are confronted with analyses that can with justification describe British politics as having been seized by Jacobins ${ }^{16}$ or McCarthyites reveals the state into which UK politics has fallen. Grey (2019b) comments that the dominance of the ultraBrexiteers in the UK government has been 'given a particular inflection by having as its leader someone who ... is so totally lacking in commitment to morality or truth'. Grey goes further to identify a deeper reality which is that Brexit 'makes liars of everyone who tries to enact it, even if they are not by nature as mendacious as Johnson'. In another telling analysis ${ }^{17}$, Grey (2019a) examines the effects of government by cult and states that ministerial pronouncements on Brexit are 'now indistinguishable from the rabid outpourings of the legions of pseudonymous Brexiter social media warriors'. It is as if, Grey concludes, 'all the seats at the cabinet table have fallen into the hands of @ bleiveinbrexit38754 accounts' [sic]. True belief, Grey writes, is 'utterly contested'.

Some kinds of lies seem indispensable to smooth relations such as when we lie to avoid hurting a friend. But even this kind of lie may not make much of an impression on the deceived friend: 'She may say, I didn't want to cause pain. What she really did not want is to have to deal with the other's pain. The lie is a short-cut through another's personality' (Rich 1979: 192). We understand the harm that lies can wreak as we know the centrality of truthfulness to just and respectful relations. The deceived person has to

\footnotetext{
${ }^{15}$ For example, The Economic Research Group, or ERG, a group of Conservative Party members of parliament who are opposed to EU membership, prominent among whom is Jacob-Rees Mogg, currently serving as Leader of the House of Commons. They have been influential in pushing Boris Johnson for a no deal Brexit.

${ }^{16}$ See Tom McTague's (April, 2019) article on the Jacobin revolution that has seized Brexit https://www. politico.eu/article/boris-johnson-brexit-fantasy-explained-britain-perpetual-revolution/.

${ }^{17} \mathrm{https}$ //chrisgreybrexitblog.blogspot.com/2019/08/government-by-cult.html.
} 
live with the knowledge that she has been manipulated, that she was unable to make choices based on the available information, and could not choose between meaningful alternatives. The value of truth is that

When someone tells me a piece of the truth which has been withheld from me, and which I needed in order to see my life more clearly, it may bring acute pain, but it can also flood me with a cold, sea-sharp wash of relief. (Rich 1979: 193)

Whereas the harm of being deceived means that

When we discover that someone we trusted can be trusted no longer, it forces us to reexamine the universe, to question the whole instinct and concept of trust. For awhile, we are thrust back onto some bleak, jutting ledge, in a dark pierced by sheets of fire, swept by sheets of rain, in a world before kinship, or naming, or tenderness exist; we are brought close to formlessness... . (Rich 1979: 192)

Some level of truthfulness is essential to society and to personal wellbeing. We need a minimal degree of trust, and trust 'is a social good to be protected just as much as the air we breathe and or the water we drink (Bok 1989: 26). When it is damaged, we all suffer.

What of the bullshitter? Is he worse than the liar? The liar deliberately promulgates a falsehood, he intends, as we have said, to deceive, and is devoted to falsity. The bullshitter is likewise unconcerned with the truth but his main concern, according to Frankfurt (2005), is embellishment and colouring of reality. There is an element of bluff in what the bullshitter states, but what he says need not be false or wrong. We are also generally more tolerant of bullshit than we are with lying; it is regarded as being less harmful, and we are more easily able to shake it off or dismiss it. The lie is something else. The liar intends, Frankfurt (2005: 51) tells us, 'to insert a particular falsehood at a specific point in a set or system of beliefs' and he does this in order 'to avoid the consequences of having that point occupied by the truth'. To successfully deceive us the liar requires 'craftsmanship, in which the teller of the lie submits to objective constraints imposed by what he takes to be the truth' (51). Unlike the bullshitter, the liar 'is inescapably concerned with truth-values. In order to invent a lie at all, he must think he knows what is true' (51-52). Ironically, the liar must be guided by the truth or what he knows to be true. The bullshitter is not so constrained. He has more freedom to improvise, to be creative and imaginative, his 'focus is panoramic rather than particular' (52). What marks out the bullshitter from the liar is that he fundamentally misrepresents his enterprise, rather than his beliefs, the facts, or state of affairs.

... the fact about himself that the liar hides is that he is attempting to lead us away from a correct apprehension of reality; we are not to know that he wants us to believe something he supposes to be false. The fact about himself that the bullshitter hides, on the other hand, is that the truth-values of his statements are of no central interest to him; what we are not to understand is that his intention is neither to report the truth nor to conceal it. (Frankfurt 2005: 53-54)

The bullshitter is not guided by the authority of truth and it is for this reason, Frankfurt concludes, that bullshit is a greater enemy of the truth than are lies. We disagree: lies 
can cause great and lasting harm. The Nazis praised the big lie in its propaganda with catastrophic consequences; vicious propaganda and deliberate lies were spread by the government during the Spanish Civil War; and currently, in the UK (and the USA, Israel, Hungary, India and countless other countries), lies damage, destroy and result in loss of livelihoods - and life.

Frankfurt accounts for the pervasiveness of bullshit on the basis of our modern communication methods and the speed by which we are expected to comment on things as they happen. As he memorably states, 'bullshit is unavoidable whenever circumstances require someone to talk without knowing what he is talking about'. It is stimulated 'whenever a person's obligations or opportunities to speak about some topic are more excessive than his knowledge of the facts that are relevant to that topic' (Frankfurt 2005: 63), a common feature in public life and social media which seem to compel many to comment on things about which they may not know much.

Social media has also resulted in the amplification of lies, bullshit and fake news which has been achieved by exploiting the information systems in which we work, and by algorithms which prioritise content that is highly clickable.

The other reason why Frankfurt believes that bullshit and lies proliferate is, as we discussed earlier, due to scepticism which denies that we can have reliable access to objective reality. Denial that there are things that can be verifiably and confidently known, or that we have the means to check whether what is claimed is true or false, is truthful or a falsehood, undermines confidence in intelligible, disinterested enquiry.

\section{Overcoming the Onslaught}

The issues outlined above are characteristic of a 'postdigital' condition; that is to say, epistemic vices are not caused by digital technologies, but they do enable their rapid proliferation. The postdigital highlights how lies, bullshit and fake news are best understood through 'a critical appraisal of the assumptions embedded in the general understanding of the digital' (Knox 2019: 357). Digital environments are socioeconomic-technical systems that require a critical attitude about how, among other things, platforms operate and algorithms work. Digital environments are spaces into which very few of us, if any, can avoid entering (through online courses, banking, news and so on). They are both a means to promote justice, equality and democracy, and their attendant virtues of truth, trust, integrity and so on; and the reverse: to destabilise these forces by deceit, lies and calculated misinformation.

Notably, the contributions within this special issue collectively highlight a nuanced and multi-layered appraisal of how lies, bullshit and fake news emerge today through a complex entanglement between technologies and material affordances, human and social practice, and historical and cultural imperatives. It is precisely to these postdigital perspectives that we argue educational research could pay more attention.

As educators we believe in the power of knowledge to transform and that knowledge itself grows out of debate, scientific inquiry and freedom to contest. But all of this pre-supposes (i) an informed public and (ii) that it is enough for them to know that 'experts' hold the keys to that knowledge. Both of these presuppositions are being undermined in today's information eco-system, for reasons outlined above. To achieve a truly informed public, the educational challenge 
seems insurmountable, but begins by understanding the networked nature of the information ecosystem in which we operate.

As our information ecosystem gets more and more complex and unpredictable, educators have a vital role to play in helping an informed public navigate what it encounters online. But it is quite simply not enough to merely supply people with scientifically grounded, credible and quality information or even to rely entirely on the skills to critically assess what they read - though these things are important. What is required is a rebuilding of trust in educational and political institutions, and in the value of truth as something that is objectively sought and highly desirable.

This process begins at the level of the individual, by stripping away the layers of complexity in our own individualised and ritualised (Bhatt and MacKenzie 2019) practices online through a process of reflection. If education is about fostering the kind of healthy scepticism necessary for challenging assumptions, then this should begin by examining how trust is accorded and truth is established in our own online and truth seeking practices.

Being reflexive in this way could allow us to look for new explanations and understand how knowledge is constructed at the level of the individual user of technology. The higher education sector has to engage in these issues. Once individuals come to see how different ways of constructing knowledge emerge online, they may begin to question more astutely the trustworthiness of the sources they use. It is also critical that academics do not resile from contesting the lies, fake news and bullshit, however challenging that seems given the levels of scepticism and active discrediting of our research that we often encounter, including accusations that we drain leftie' propaganda into the minds of our students. Critically, we must continue to advance knowledge and understanding, as truthfully, critically and rigorously as we possibly can.

Acknowledgements We would like to thank Ian Thatcher, Christine Bower and Jennifer Rose for reading early drafts of this paper, and the anonymous reviewers of the paper who, in the spirit of this Special Issue, offered constructive advice and warm endorsement.

Open Access This article is distributed under the terms of the Creative Commons Attribution 4.0 International License (http://creativecommons.org/licenses/by/4.0/), which permits unrestricted use, distribution, and reproduction in any medium, provided you give appropriate credit to the original author(s) and the source, provide a link to the Creative Commons license, and indicate if changes were made.

\section{References}

Bhatt, I., \& MacKenzie, A. (2019). Just Google it! Digital literacy and the epistemology of ignorance. Teaching in Higher Education, 24(3), 302-317. https://doi.org/10.1080/13562517.2018.1547276.

Blair, T. (2007). Blair's speech full text. The Guardian, 10 May. https://www.theguardian.com/politics/2007 /may/10/labourleadership.labour2. Accessed 5 October, 2019.

Boffey, D. (2019). Boris Johnson humiliated by Luxembourg PM at 'empty chair' press conference. The Guardian, 17 September. https:/www.theguardian.com/politics/2019/sep/16/johnson-humiliated-byluxembourg-pm-at-empty-chair-press-conference. Accessed 18 September, 2019.

Bok, G. (1989). Lying: moral choice in public life (2nd ed.). New York: Vintage.

Carr, E. H. (1961). What is history? Middlesex, England: Penguin books.

de Montaigne, M. (1987). The complete essays. London: Penguin. 
Dougan, M., \& O'Brien, C. (2019). Reflections on law and impact in the light of Brexit. The Law Teacher, 53(2), 197-211. https://doi.org/10.1080/03069400.2019.1582198.

Frankfurt, H. G. (2005). On bullshit. Princeton: Princeton University Press.

Frankfurt, H. G. (2006). On truth. New York: Alfred A. Knopf.

Goda, N. J. W. (2002). AJP Taylor, Adolf Hitler, and the origins of the Second World War. The International History Review, 23(1), 97-124.

Golebiewski, M., \& Boyd, D. (2018). Data voids: where missing data can easily be exploited. Data \& Society, 29 October. https://datasociety.net/output/data-voids-where-missing-data-can-easily-be-exploited/. Accessed 13 October, 2019.

Grey, C. (2019a). Government by cult. The Brexit Blog, 2 August. https://chrisgreybrexitblog.blogspot. com/2019/08/government-by-cult.html. Accessed 21 September, 2019.

Grey, C. (2019b). Revolution and counter-revolution. The Brexit Blog, 13 September. https://chrisgreybrexitblog.blogspot.com/2019/09/revolution-and-counter-revolution.html. Accessed 21 September, 2019.

Guba, E. G., \& Lincoln, Y. S. (1981). Effective evaluation: improving the usefulness of evaluation results through responsive and naturalistic approaches. San Francisco, CA: Jossey-Bass.

Hastings, M. (2019). I was Boris Johnson's boss. He is utterly unfit to be prime minister. The Guardian, 24 June. https://www.theguardian.com/commentisfree/2019/jun/24/boris-johnson-prime-minister-tory-partybritain. Accessed 21 September, 2019.

Knox, J. (2019). What does the 'postdigital' mean for education? Three critical perspectives on the digital, with implications for educational research and practice. Postdigital Science and Education, 1(2), 357370. https://doi.org/10.1007/s42438-019-00045-y.

MacKenzie, A., \& Bhatt, I. (2018). Lies, Bullshit and Fake News: Some Epistemological Concerns. Postdigital Science and Education. https://doi.org/10.1007/s42438-018-0025-4.

Malik, K. (2017). Not post-truth as too many 'truths'. Pandaemonium, 5 February. https://kenanmalik. com/2017/02/05/not-post-truth-as-too-many-truths/. Accessed 6 October, 2019.

McTague, T. (2019). British Jacobins on the march in Brexit revolution. Politico, 19 April. https://www. politico.eu/article/boris-johnson-brexit-fantasy-explained-britain-perpetual-revolution/. Accessed 21 September, 2019.

Morse, M. M., Barrett, M., Mayan, M., Olson, K., \& Spiers, J. (2002). Verification strategies for establishing reliability and validity in qualitative research. International Journal of Qualitative Methods, 1(2), 13-32. https://doi.org/10.1177/160940690200100202.

Orwell, G. (1968). Homage to Catalonia; and, Looking Back on the Spanish War. London: Penguin.

Orwell, G. (2000/1943). In S. Orwell \& I. Angus (Eds.), My country left or right, 1940-43. Boston: Non Pareil Books.

Rich, A. (1979). On lies, secrets and silence. Selected prose 1966-1978. New York: W. W. Norton \& Company.

Rose, J. (2019). To believe or not to believe: an epistemic exploration of fake news, truth and the limits of knowing. Post Digital Science and Education.

Taylor, A. J. P. (1961). The origins of the Second World War. London: Penguin.

The Supreme Court (2019). R (on the application of Miller) (Appellant) v The Prime Minister (Respondent) Cherry and others (Respondents) v Advocate General for Scotland (Appellant) (Scotland). On appeals from: [2019] EWHC $2381(Q B)$ and [2019] CSIH 49. 24 September. https://www.supremecourt. uk/decided-cases/index.html. Accessed 1 November 2019.

Williams, B. (2002). Truth and truthfulness: an essay in genealogy. Princeton and Oxford: Princeton University Press. 